\title{
Tc-99m MDP Bone SPECT/CT Findings of a Patient Detected with a New Mutation in LEMD3 Gene: A Case of Osteopoikilosis
}

\author{
LEMD3 Geninde Yeni Mutasyon Saptanan Osteopoikiloz Olgusunda Tc-99m MDP Kemik \\ SPECT/BT Bulgular
}

\author{
(D) Güler Silov \\ (1) Zeynep Erdoğan! \\ Murat Erdoğan², \\ Ayşegül Özdall \\ Hümeyra Gençerl, \\ (D) Tayfun Akalın \\ D Seyhan Karaçavuş \\ IUniversity of Health Sciences, Kayseri Training and Research Hospital, Clinic of Nuclear Medicine, Kayseri, Turkey \\ UUniversity of Health Sciences, Kayseri Training and Research Hospital, Clinic of Molecular Biology and Genetics, Kayseri, Turkey \\ 3 University of Health Sciences, Kayseri Training and Research Hospital, Clinic of Rheumatology, Kayseri, Turkey
}

\begin{abstract}
Osteopoikilosis is an inherited condition with autosomal dominant trait resulting in sclerotic foci throughout the skeleton. It has been suggested that loss-of-function mutations of LEMD3 gene located on 12q14.3 result in osetopoikilosis. A bp heterozygote deletion was detected in our patient at the cytosine nucleotide at position 1105 with molecular genetic analysis. Although this mutation has not been previously described, it was considered to be the most likely cause of the disease in our patient due to frame shift and premature stop codon formation. As in our case, three phase bone scintigraphy and whole body imaging did not reflect the true extent of lesion sites and lesion activity. SPECT/CT images could reflect lesion location and activity more accurately, and could be a good alternative for differential diagnosis of unexplained bone pain and sclerotic lesions in one examination.
\end{abstract}

Keywords: LEMD3 gene, osteopoikilosis, Tc-99m MDP, SPECT/CT

Öz

Osteopoikiloz kemik doku boyunca kemik adacıkları ile karakterize, otozomal dominant geçiş gösteren herediter bir hastalıktır. Mevcut literatürde, 12q14.3 üzerinde bulunan LEMD3 genindeki mutasyonların sebep olduğu gösterilmiştir. Hastamızda yapılan moleküler genetik analizde 'Yeni Nesil Dizi Analizi' 1105. pozisyondaki sitozin nükleotidinde bir bp'lik heterozigot delesyon tespit edilmiştir. Bu mutasyon, daha önceden literatürde tanımlanmamış olmakla birlikte; çerçeve kaymasına neden olması ve erken stop kodon oluşturması sebebiyle yüksek olasılıkla hastalık nedeni olarak değerlendirilmiştir. Ancak üç fazlı kemik sintigrafisi ve tüm vücut taraması, bu olguda olduğu gibi gerçek lezyon sayısı ve lezyon aktivitesini yansıtmamaktadır. SPECT/BT görüntüleme bu açıdan iyi bir seçim olarak görülmektedir.

Anahtar kelimeler: LEMD3 geni, osteopoikiloz, TC-99m MDP, SPECT/BT

Address for Correspondence: Güler Silov MD, University of Health Sciences, Kayseri Training and Research Hospital, Clinic of Nuclear Medicine, Kayseri, Turkey Phone: +90 3523368884 E-mail: gulersilov@yahoo.com ORCID ID: orcid.org/0000-0002-4658-8634

Received: 09.06.2017 Accepted: 15.10.2017

${ }^{\circ}$ Copyright 2018 by Turkish Society of Nuclear Medicine

Molecular Imaging and Radionuclide Therapy published by Galenos Yayınevi. 

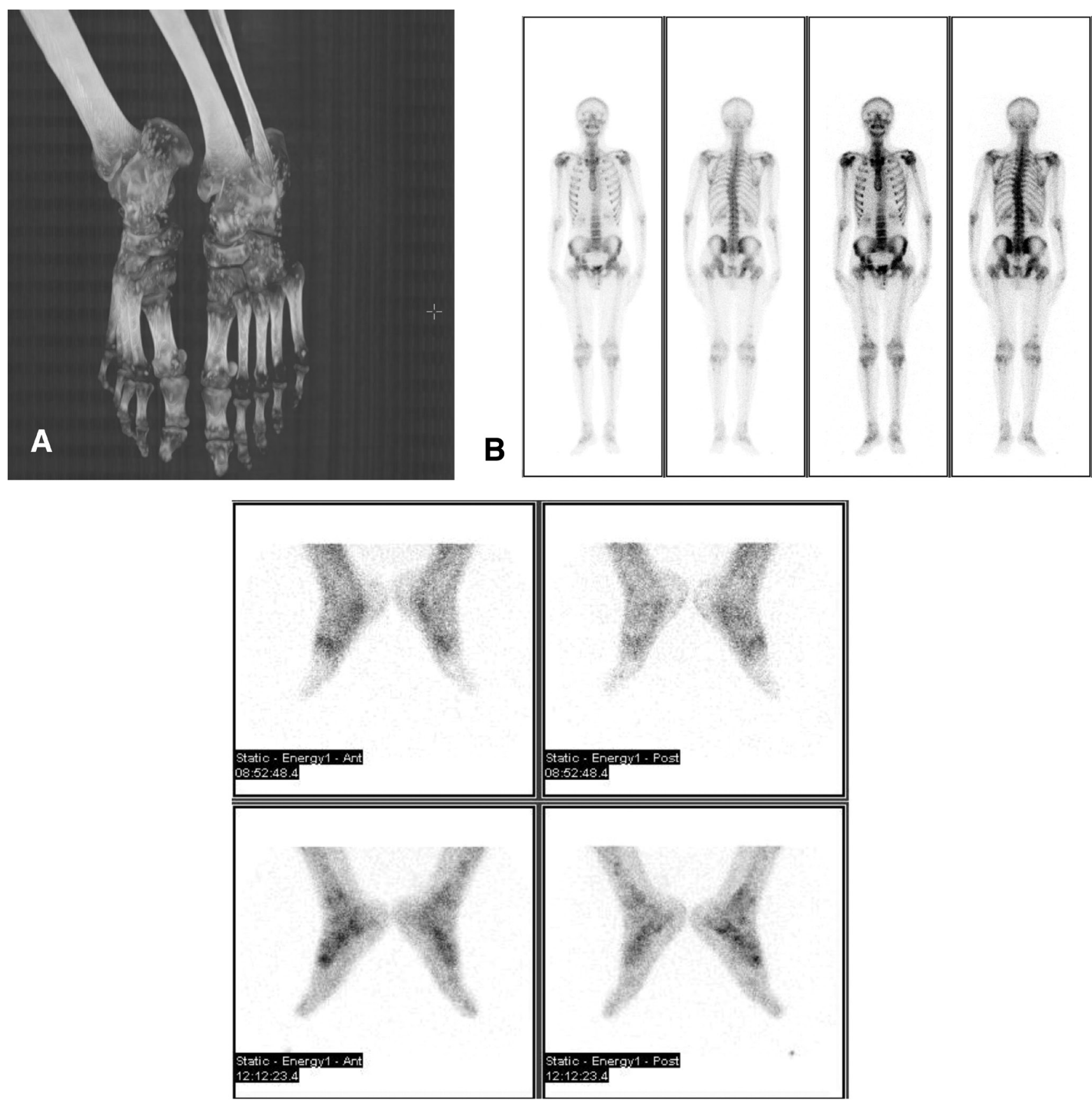

C

Figure 1. A 20-year-old man was referred to our department with right foot pain. The plain X-ray showed numerous small lesions distributed along the feet (A). A three phase Tc-99m methylene diphosphonate (MDP) bone scan of the foot, whole body scanning along with feet and pelvic-thoracic SPECT/CT were performed. Whole body images showed relative irregularly increased focal MDP uptake on the long bones and pelvic region (B). The late phase static images of feet irregularly increased focal MDP uptake (C). 

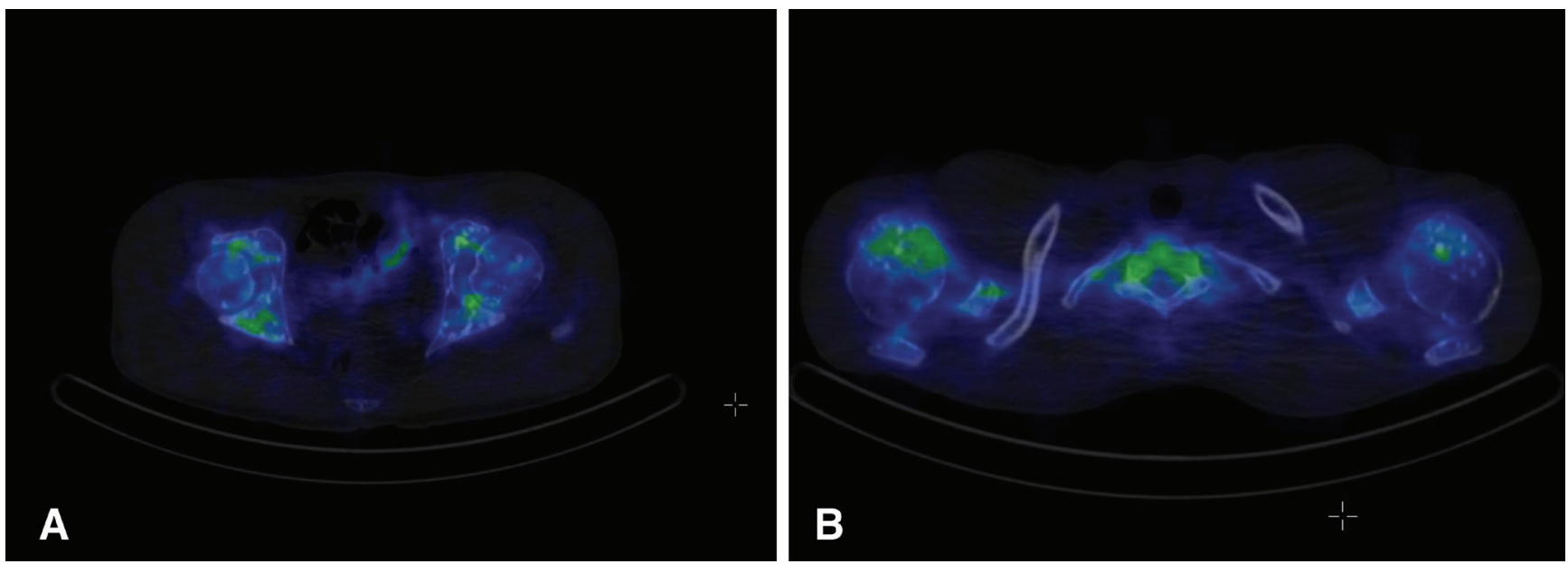

Figure 2. Multiple, sclerotic lesions were detected in thoracic bones, shoulders, and both femur and pelvic bones by CT but radiotracer uptake was observed in some sclerotic lesions on SPECT-CT images (A, B). Laboratory tests were within normal limits except a slightly elevated alkaline phosphatase value of $126 \mathrm{U} / \mathrm{L}$ (range: $30-120 \mathrm{U} / \mathrm{L}$ ).

Osteopoikilosis is an inherited condition with autosomal dominant trait that results in numerous sclerotic foci throughout the skeleton (1). Previous studies have reported that these lesions are symmetric but randomly distributed, with increased concentrations at the carpal and tarsal bones, as well as at the ends of the long bones $(2,3)$. Lesions are reported to be located less in the skull, rib, vertebra, and mandible (1).

Recently, whole-genome linkage analysis of affected individuals resulted in identification of a loss-of-function mutation in gene LEMD3 at position 12q14.3. LEMD3 is believed to function in bone morphogenetic protein (BMP) signaling by interacting with the family of SMAD proteins downstream from transforming growth factor-beta (TGF-beta) to regulate bone formation $(4,5)$. It has been reported that LEMD3 can antagonize both BMP and TGF-beta signaling in human cells (6). Molecular genetic analysis was performed in our patient, and a bp heterozygote deletion was detected in the cytosine nucleotide at position 1105. This mutation has not been previously described in the literature, but is considered to be the most likely cause of the disease due to frame shift and premature stop codon formation.

Histologically, the sclerotic foci correspond to old and inactive remodeling of spongiform lamellar trabeculae with a gross nodular or star-like appearance (7). Sclerotic lesions are classically inactive on whole body scintigraphy (8,9). For this reason, a Tc-99m bone scan is sufficiently diagnostic and usually returns to normal in cases of osteopoikilosis. There have been a few cases reported in the literature of abnormal bone scans in patients with osteopoikilosis (10). In such cases, the pattern of increased uptake is usually symmetric and localized to the distal ends of tubular, carpal, and tarsal bones. This may correspond to active bone remodeling of these multiple foci, which has also been reported in pathologic specimens of osteopoikilosis. As in our patient, localized three phase bone scintigraphy and whole body scanning did not reflect the true extent of lesion site and activity. However, SPECT/CT images could reflect lesion location and activity more accurately, and could be a good alternative for differential diagnosis of unexplained bone pain and sclerotic lesions in one examination. 


\section{Ethics}

Informed Consent: Consent form was filled out by all participants.

Peer-review: Externally peer-reviewed.

\section{Authorship Contributions}

Surgical and Medical Practices: G.S., M.E., T.A., Concept: G.S., Z.E., Design: G.S., A.Ö., Data Collection or Processing: G.S., M.E., T.A., Analysis or Interpretation: G.S., H.G., S.K., Literature Search: G.S., Writing: G.S.

Conflict of Interest: No conflict of interest was declared by the authors.

Financial Disclosure: The authors declared that this study received no financial support.

\section{References}

1. Benli IT, Akalin S, Boysan E, Mumcu EF, Kiş M, Türkoğlu D. Epidemiological, clinical and radiological aspects of osteopoikilosis. J Bone Joint Surg Br 1992;74:504-506.
2. Van Hul, Vanhoenacker F, Balemans W, Janssens K, De Schepper AM. Molecular and radiological diagnosis of sclerosing bone dysplasias. Eur J Radiol 2001;40:198-207.

3. Ben-Asher E, Zelzer E, Lancet D. LEMD3: the gene responsible for bone density disorders (osteopoikilosis). Isr Med Assoc J 2005;7:273-274.

4. Korman B, Wei J, Laumann A, Ferguson P, Varga J. Mutation in LEMD3 (Man1) Associated with Osteopoikilosis and Late-Onset Generalized Morphea: A New Buschke-Ollendorf Syndrome Variant. Case Rep Dermatol Med 2016;2016:2483041.

5. Ito Y, Miyazono K. RUNX transcription factors as key targets of TGF- $\beta$ superfamily signaling. Curr Opin Genet Dev 2003;13:43-47.

6. Pan D, Estevez-Salmeron LD, Stroschein SL, Zhu X, He J, Zhou S, Luo $\mathrm{K}$. The integral inner nuclear membrane protein MAN1 physically interacts with the R-Smad proteins to repress signaling by the transforming growth factor- $\beta$ superfamily of cytokines. J Biol Chem 2005;280:15992-6001.

7. Lagier R, Mbakop A, Bigler A. Osteopoikilosis: a radiological and pathological study. Skeletal Radiol 1984;11:161-168.

8. de Vernejoul MC, Kornak U. Heritable sclerosing bone disorders: presentation and new molecular mechanisms. Ann N Y Acad Sci 2010;1192:269-277.

9. Tsai SY, Wang SY, Shiau YC, Wu YW. Benign incidental findings of osteopoikilosis on Tc-99m MDP bone SPECT/CT: A case report and literature review. Medicine (Baltimore) 2016:95:e3868.

10. An YS, Yoon JK, Lee MH, Joh CW, Yoon SN. Abnormal bone scan in an adult with osteopoikilosis. Clin Nucl Med 2004;29:856-858. 